\title{
Vulvar Cancer pN3 TNM Finding v8
}

National Cancer Institute

\section{Source}

National Cancer Institute. Vulvar Cancer pN3 TNM Finding v8. NCI Thesaurus. Code C139617.

Vulvar cancer with fixed or ulcerated regional lymph node metastasis. (from AJCC 8th Ed.) 